\title{
Temperature Effect on Listeria Monocytogenes Planktonic Growth and Biofilm-Forming Ability
}

\author{
Joana Catarina Andrade ${ }^{1}$; Rita Bernardo²; António Salvador Barreto ${ }^{3}$ Telmo Nunes ${ }^{4}$ Ana Rita Henriques ${ }^{5 *}$ \\ ${ }^{1} \mathrm{MSc}$ in Microbiology, University of Lisbon, Portugal. \\ ${ }^{2} \mathrm{MSc}$ in Microbiology, University of Lisbon, Portugal. \\ ${ }^{3} \mathrm{PhD}$ in Veterinary Sciences, Technical University of Lisbon, Portugal. \\ ${ }^{4} \mathrm{MSc}$ in Veterinary Public Health, Technical University of Lisbon, Portugal. \\ ${ }^{5} \mathrm{PhD}$ in Veterinary Sciences, University of Lisbon, Portugal.
}

\author{
*Corresponding Author(s): Ana Rita Henriques \\ CIISA - Centre for Interdisciplinary Research in Animal \\ Health, Faculty of Veterinary Medicine, University of \\ Lisbon, Avenida da Universidade Técnica, 1300-477 \\ Lisboa. \\ Tel: 00-351-213-652-834; \\ Email: anaritah@fmv.ulisboa.pt
}

Received: Nov 03, 2020

Accepted: Dec 29, 2020

Published Online: Dec 31, 2020

Journal: Journal of Veterinary Medicine and Animal Sciences

Publisher: MedDocs Publishers LLC

Online edition: http://meddocsonline.org/

Copyright: (C) Henriques AR (2020). This Article is

distributed under the terms of Creative Commons

Attribution 4.0 International License

Keywords: Listeria monocytogenes; Isothermal growth; Planktonic; Biofilm, Temperature.

\begin{abstract}
Listeria monocytogenes is an important foodborne pathogen with the capacity to grow at low temperatures and the ability to form biofilms. These features are particularly significant to food business operators producing readyto-eat foods with a long refrigerated shelf-life not undergoing any listericidal treatment before consumption.
\end{abstract}

Objectives: This work aims to assess the temperature effect on L. monocytogenes growth in planktonic suspension and in mono-species biofilms.

Methods and results: Isothermal planktonic growth at $12^{\circ} \mathrm{C}$ and $37^{\circ} \mathrm{C}$ was assayed using viable cell counts and optical density measurements that revealed a strong positive correlation, confirming the reliability of combining both methods to estimate L. monocytogenes concentration. Experimental data were then fitted to Baranyi and Roberts primary predictive model and the estimated growth parameters confirmed that $\mu \mathrm{max}$ at $37^{\circ} \mathrm{C}(0.375 \pm 0.072 \mathrm{log} \mathrm{cfu} /$ $\mathrm{ml} / \mathrm{h})$ was higher than at $12^{\circ} \mathrm{C}(0.054 \pm 0.001 \mathrm{log} \mathrm{cfu} / \mathrm{ml} / \mathrm{h})$, with identical L. monocytogenes final concentrations which emphasizes its ability to grow at refrigerated temperatures. Experimental results from the isothermal growth assay and ComBase Predictor growth model were similar, with slightly higher estimated $\mu \max \left(37^{\circ} \mathrm{C}: 0.480 \log \mathrm{cfu} / \mathrm{ml} / \mathrm{h}\right.$; $12^{\circ} \mathrm{C}: 0.068 \log \mathrm{cfu} / \mathrm{ml} / \mathrm{h}$ ) in the predictor growth model. The studied strains demonstrated biofilm-forming ability at $12^{\circ} \mathrm{C}, 20^{\circ} \mathrm{C}$ and $30^{\circ} \mathrm{C}$ after 5 days of growth. No significant differences in biofilm formation at different temperatures were detected considering viable cell counts values, but when using crystal violet staining optical density results significant differences were found, with the highest formation occurring at 30 ㄷ. A positive strong correlation was found between viable cell counts and crystal violet staining optical

Cite this article: Andrade JC, Bernardo R, Barreto AS, Nunes T, Henriques AR. Temperature Effect on Listeria Monocytogenes Planktonic Growth and Biofilm-Forming Ability. J Vet Med Animal Sci. 2020; 3(1): 1044. 
density results. In fact, both methods complement each other, because while viable cell counts measures viable cells, crystal violet staining optical density considers total biomass (viable and non-viable cells and extracellular matrix components). Nevertheless, in this work all L. monocytogenes strains revealed to be weak biofilm producers.

Conclusion: Overall, this studys results contribute with important initial information on L. monocytogenes growth and biofilm formation to further assist predictive growth modeling in food matrices and environments, also enabling subsequent quantitative microbial risk assessment, to improve pathogen's control.

\section{Introduction}

Listeria monocytogenes is the causative agent of human listeriosis, an important foodborne disease with a high fatality rate particularly in new-born infants, pregnant woman, elderly and immunocompromised patients [1-3]. Listeriosis is almost entirely transmitted through the ingestion of contaminated foods [4].

The ability to colonize food environments, enduring an extensive variety of physicochemical conditions and different processing hurdles, is due to L. monocytogenes physiological and ecological traits $[5,6]$.

After gaining access to a food facility, through incoming raw materials and ingredients, packaging materials, or even food handlers, L. monocytogenes is able to persist for months or years within the food premises, especially in food contact surfaces $[7,8]$.

L. monocytogenes can adhere to different surfaces within the food industry, such as plastic, polypropylene, rubber, stainless steel, glass and produce biofilms [7,9]. In the biofilm, bacteria are embedded by an extracellular matrix able to function as a structural scaffold and defense barrier [8]. Once established, biofilms confer protection against harsh environmental conditions, enabling to sustain the survival of bacteria and tolerance to food environment related hurdles [10]. These persistent strains have been linked to recurring contamination of finished products [10-12]. Although this cross-contamination transfers low levels of L. monocytogenes onto food, its psychrotrophic nature enables growth during refrigerated storage, reaching levels that might represent an increased risk to the consumer [13-15]. This is even more concerning if temperature fluctuation occurs in any of the production and distribution stages, or even at the household level, and if the food is a ready-to-eat product, not requiring a listericidal treatment before consumption [16-18].

This work aims to assess L. monocytogenes growth in planktonic suspension and in mono-species biofilms, depicting food and food-producing environment conditions.

The resulting data in culture media and different temperatures will provide important initial information to further assist predictive growth modeling in food matrices and environments, also enabling subsequent quantitative microbial risk assessments.

\section{Materials and methods}

\section{Selection and revival of L. monocytogenes strains}

To account for variation in growth and survival among Liste- ria monocytogenes strains and to have representatives of the three serogroups more frequently related to human disease, three reference strains were assessed: L. monocytogenes CECT 4031 (serogroup Ila), L. monocytogenes CECT 935 (serogroup $\mathrm{IVb}$ ) and L. monocytogenes CECT 937 (serogroup Ilb).

For strains' revival, stock cultures stored at $-80^{\circ} \mathrm{C}$ in preservation cryotubes containing Brain Heart Infusion (BHI) broth (Scharlab, S.L, Barcelona, Spain) supplemented with $15 \%$ glycerol (Merck KGaA, Darmstadt, Germany) were thawed and 100 $\mu \mathrm{l}$ of inoculum was transferred into $5 \mathrm{ml}$ of BHI broth. After 24 hours (h) of incubation at $37^{\circ} \mathrm{C}$, a loop $(10 \mu \mathrm{l})$ of inoculum was streaked onto $\mathrm{BHI}$ agar (Scharlab, S.L.) and incubated at $37^{\circ} \mathrm{C}$ for $24 \mathrm{~h}$.

\section{L. monocytogenes isothermal growth in BHI broth}

An isolated colony of L. monocytogenes was suspended in $5 \mathrm{ml}$ of $\mathrm{BHI}$ broth (Scharlab, S.B.). The suspension was incubated at constant temperature of $12^{\circ}$ and $37^{\circ} \mathrm{C}$. Each sample was periodically examined to assess the growth of L. monocytogenes. For that, bacterial suspensions' optical density at 600 $\mathrm{nm}\left(\mathrm{OD}_{600 \mathrm{~nm}}\right)$ was measured on a spectrophotometer Ultrospec 2000 (Pharmacia Biotech, Cambridge, England) at regular time intervals. Together with $\mathrm{OD}_{600 \mathrm{~nm}}$, enumeration of viable bacterial cells (VCC) at regular time intervals was also performed. Three independent growth experiments were performed for each temperature condition $\left(37^{\circ} \mathrm{C}\right.$ and $\left.12^{\circ} \mathrm{C}\right)$, in each of the considered sampling time points (Table 1 ).

Table 1: Sampling time points used to assess $L$. monocytogenes CECT 4031 growth in $\mathrm{BHI}$ broth at $37^{\circ} \mathrm{C}$ and $12^{\circ} \mathrm{C}$.

\begin{tabular}{|c|c|c|c|c|c|c|c|c|}
\hline \multicolumn{9}{|c|}{ Sampling time } \\
\hline \multicolumn{3}{|c|}{ Incubation at $37^{\circ} \mathrm{C}$} & \multicolumn{5}{c|}{ Incubation at $12^{\circ} \mathrm{C}$} \\
\hline $2 \mathrm{~h}$ & $10 \mathrm{~h}$ & $18 \mathrm{~h}$ & $26 \mathrm{~h}$ & $4 \mathrm{~h}$ & $20 \mathrm{~h}$ & $96 \mathrm{~h}$ & $192 \mathrm{~h}$ & $288 \mathrm{~h}$ \\
\hline $4 \mathrm{~h}$ & $12 \mathrm{~h}$ & $20 \mathrm{~h}$ & & $8 \mathrm{~h}$ & $24 \mathrm{~h}$ & $120 \mathrm{~h}$ & $216 \mathrm{~h}$ & \\
\hline $6 \mathrm{~h}$ & $14 \mathrm{~h}$ & $22 \mathrm{~h}$ & & $12 \mathrm{~h}$ & $48 \mathrm{~h}$ & $144 \mathrm{~h}$ & $244 \mathrm{~h}$ & \\
\hline $8 \mathrm{~h}$ & $16 \mathrm{~h}$ & $24 \mathrm{~h}$ & & $16 \mathrm{~h}$ & $72 \mathrm{~h}$ & $168 \mathrm{~h}$ & $264 \mathrm{~h}$ & \\
\hline
\end{tabular}

Curve fitting and growth parameters estimation

Growth curves were fitted to Baranyi and Roberts primary predictive model [19] (Equations 1-3), using DMFit online (Quadram Institute, Norwich, United Kingdom), to estimate maximum specific growth rate $\left(\mu_{\max }\right)$, lag time $(\lambda)$, initial and final concentration $\left(C_{0}\right.$ and $C_{f}$, respectively); $R$-square $\left(R^{2}\right)$ and standard error of fit (SE) were used to evaluate the performance of the models built in this study. A fitting method for repeated measures was applied considering the different replicates analyzed in each time point.

$$
N(t)=N_{0}+\mu_{\max } A(t)-\ln \left[1+\frac{e^{\mu_{\max } A(t)}-1}{e^{\left(N_{\max }-N_{0}\right)}}\right]
$$

$$
A(t)=t+\frac{1}{\mu_{\max }} \ln \left(\frac{e^{\left(-\mu_{\max }{ }^{t}\right)}+q_{0}}{1+q_{0}}\right)
$$

$$
\lambda=\frac{\ln \left(1+\frac{1}{q_{0}}\right)}{\mu_{\max }}
$$


Where: $\mathrm{N}(\mathrm{t})=\log$ of cell concentration $(\mathrm{cfu} / \mathrm{ml}(\mathrm{g}))$ at time $\mathrm{t}$ (h); $\mathrm{NO}=\log$ of initial cell concentration ( $\mathrm{cfu} / \mathrm{ml}(\mathrm{g})$ ); $\mu \mathrm{max}=\max -$ imum specific growth rate (log $\mathrm{cfu} / \mathrm{ml}(\mathrm{g}) / \mathrm{h})$; Nmax= log of maximum cell concentration; $\mathrm{q} 0=$ parameter expressing the physiological state of cells when $t=t 0 ; \lambda=$ lag time (h). In this work, $\mu$ max was based on the inflection of the growth curve slope in the exponential phase [20].

The resulting growth curves and parameters were compared to predicted values generated by ComBase Predictor Growth Model (ComBase, Hobart, Australia). ComBase model was run with the following selected parameters: Initial level= 4.5 log $\mathrm{cfu} / \mathrm{ml} ; \mathrm{pH}=7.4$ and $\mathrm{a}_{\mathrm{w}}=0.997$ were $\mathrm{BHI}$ broth data.

\section{Calibration curves}

To study $\mathrm{OD}_{600 \mathrm{~nm}}$ and cell count (cfu/ml) relation, calibration curves were prepared. For that, L. monocytogenes CECT 4031 were cultured on $\mathrm{BHI}$ agar (Scharlab, S.B.) for $18 \mathrm{~h}$ at $37^{\circ} \mathrm{C}$. Afterwards, cultures were transferred to $10 \mathrm{ml}$ of tryptone salt broth (Scharlab, S.B.), resulting in a suspension with an $\mathrm{OD}_{600 \mathrm{~nm}}$ of $0.4-0.5$ and serial dilutions were prepared. Serial dilutions $\mathrm{OD}_{600 \mathrm{~nm}}$ were measured and correlated with $\mathrm{cfu} / \mathrm{ml}$ obtained in plate counts on BHI agar (Scharlab, S.B.). This assay was performed in triplicate.

\section{Biofilm formation assay}

The protocol proposed by Romanova, Gawande, Brovko and Griffiths [21] was used with some modifications to obtain a 5-day L. monocytogenes mono-cultural biofilm. A single colony of each selected strain was inoculated in Buffered Peptone Water (BPW) (Scharlab, S.B), incubating overnight at $30^{\circ} \mathrm{C}$. Bacterial suspension $\mathrm{OD}_{600 \mathrm{~nm}}$ was adjusted to 0.1 approximately, in Ultrospec 2000 (Pharmacia Biotech), to obtain a concentration of $8 \log \mathrm{cfu} / \mathrm{ml}$, according to the above mentioned calibration curve. For each strain, $4 \mu \mathrm{l}$ were transferred into three separate wells of polystyrene flat-bottomed microtiter plates (Normax, Marinha Grande, Portugal) filled with $200 \mu$ of BPW. Three wells were used as negative controls, containing only BPW. The plates were statically incubated at $30^{\circ} \mathrm{C}$ for 5 days. The solution was then removed from the wells that were rinsed with sterile distilled water to remove loosely associated bacteria and the attached biofilms were evaluated by Viable Cells Counts (VCC) and Crystal violet staining (cvOD). This assay was performed in triplicate, with three replicates for each strain. L. monocytogenes CECT 4031 and CECT 935 were further assess for biofilm formation at $12^{\circ} \mathrm{C}$ and $20^{\circ} \mathrm{C}$. For that, the abovementioned procedure was followed and the plates were statically incubated at $12{ }^{\circ} \mathrm{C}$ and $2{ }^{\circ} \mathrm{C}$ for 5 days.

\section{Biofilm assessment by viable cells counts}

The biofilm was detached from the well surface with 100 $\mu \mathrm{l}$ of BPW using a mini cell scraper and sonicated (Ultrasonic bath MXB14, Grant Instruments, England) for $5 \mathrm{~min}$ to detach and collect sessile cells. Another $100 \mu \mathrm{l}$ of BPW were pipetted into each well, serial 10 -fold dilutions were prepared and $10 \mu \mathrm{l}$ samples were dropped onto the surface of a Tryptone Soy Agar (TSA) (Scharlab, S.B) plate. Colonies were enumerated after overnight incubation at $30^{\circ} \mathrm{C}$ in a stereoscopic magnifier (Nikon SMZ645, Tokyo, Japan).

\section{Biofilm assessment by crystal violet staining}

The microtiter plate was left air drying for $45 \mathrm{~min}$ in the laminar flow hood. Biofilm was stained using $220 \mu$ of $0.1 \%$ crystal violet (bioMérieux, France) solution for $15 \mathrm{~min}$ at room temper- ature. After stain removal, the wells were washed three times with sterile distilled water and left air drying for $30 \mathrm{~min}$ in the laminar flow hood. To quantify adhered cells, $220 \mu \mathrm{l}$ of detaining solution (ethanol: Acetone 80:20 v/v) were added to each well for $15 \mathrm{~min}$ at room temperature. The microtiter plate was then shaken (Ultrasonic bath MXB14, Grant) for 5 min and the Crystal Violet OD (cvOD) was measured in SpectraMax 340PC (Molecular Devices, California, USA). Each absorbance value was corrected by subtracting the average absorbance readings of the blank control wells.

Adherence capability was based on the cVOD exhibited by bacterial biofilms, according to Stepanović, Cirković, Ranin, and Svabić-Vlahović [22]. The cut-off cvOD (cvODc) was defined as three standard deviations above the negative control mean cVOD. The strains were classified as no biofilm producers (cvOD $\leq \mathrm{ODc}$ ), weak biofilm producers (cvODc $\leq \mathrm{OD} \leq 2 \times \mathrm{ODc}$ ), moderate biofilm producers ( $2 \times \mathrm{cvODc} \leq \mathrm{cvOD} \leq 4 \times \mathrm{cvODc})$ and strong biofilm producers $(4 \times$ cvODc $<$ cvOD).

\section{Data analyses}

All quantitative data are presented as mean values with Standard Deviation (SD) from three independent experiments.

$\mathrm{OD}_{600 \mathrm{~nm}}$ and VCC data were used to fit a linear regression in Microsoft Excel 2016 software (Microsoft Corporation, Redmond, USA).

Pearson's correlation analysis was performed in GraphPad software Prism 5 (GraphPad Software, La Jolla, USA) to relate $\mathrm{OD}_{600 \mathrm{~nm}}$ and experimental VCC values.

The calibration curve was obtained from the following equation:

(4) $\mathrm{cfu} / \mathrm{ml}=$ slope $\times$ OD600nm + interception.

For L. monocytogenes growth characterization, VCC experimental results were adjusted using DMFit Online (Quadram Institute, Norwich, United Kingdom), which was also used to estimate growth related parameters.

To assess L. monocytogenes biofilm formation parameters at different temperatures $\left(12^{\circ} \mathrm{C}, 20^{\circ} \mathrm{C}\right.$ and $\left.30^{\circ} \mathrm{C}\right)$, Pearson's correlation analyses were used to evaluate the interdependency of CVOD and VCC. Two-way ANOVA was used to investigate the temperature effect on biofilm formation.

\section{Results \& discussion}

\section{Listeria monocytogenes isothermal growth in $\mathrm{BHI}$ broth}

Growth rates of L. monocytogenes were studied at different temperatures in a defined medium (BHI). L. monocytogenes CECT 4031 was chosen since it is the type strain for this specie [23].

The selected temperatures were $37^{\circ} \mathrm{C}$, corresponding to L. monocytogenes' optimal growth temperature [24,25], and $12^{\circ} \mathrm{C}$, which is used in food producing rooms at industrial facilities [26].

Figure 1 shows the resulting growth curves based on $\mathrm{L}$. monocytogenes CECT $4031 \mathrm{OD}_{600 \mathrm{~nm}}$ values in $\mathrm{BHI}$ at each sampling time point, incubated for 26 hours at $37^{\circ} \mathrm{C}(\mathrm{A})$ and for 12 days at $12^{\circ} \mathrm{C}(\mathrm{B})$. 

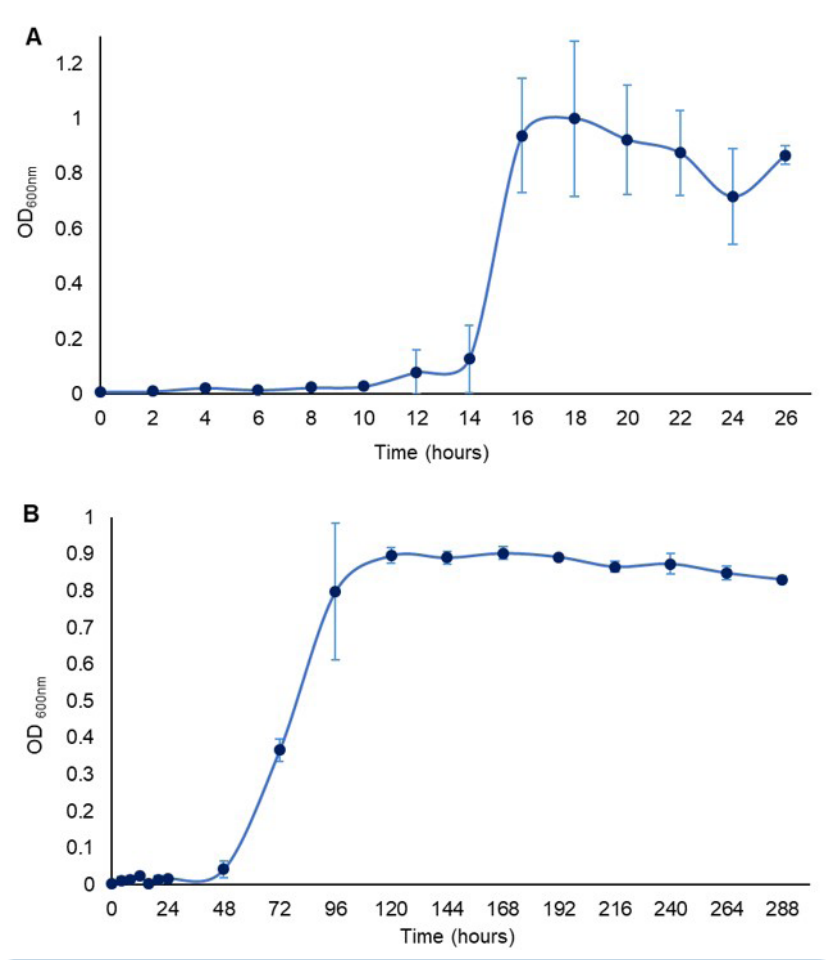

Figure 1: Growth curves of $L$. monocytogenes CECT 4031 at (A) $37^{\circ} \mathrm{C}$ for $26 \mathrm{~h}$, and (B) at $12^{\circ} \mathrm{C}$ for 12 days, obtained from average and standard deviation (error bars) of $\mathrm{OD}_{600 \mathrm{~nm}}$ measurements.

L. monocytogenes CECT 4031 growth occurred at both temperatures, although differences were observed (Figure 1). At $37^{\circ} \mathrm{C}$ a lag phase of approximately 10 hours was observed, followed by an exponential growth phase from $10 \mathrm{~h}$ to $18 \mathrm{~h}$. From then on until the end of the incubation time ( $26 \mathrm{~h})$, stationary phase was observed. The maximum $\mathrm{OD}_{600 \mathrm{~nm}}$ value was $0.999 \pm$ 0.280 at 18 h. Mytilinaios et al. (2012), when studying growth rate of L. monocytogenes in tryptone soya broth at $37^{\circ} \mathrm{C}$, obtained an average maximum optical density of 0.99 .

At $12^{\circ} \mathrm{C}$ the lag phase lasted approximately 48 hours, and from $48 \mathrm{~h}$ to $120 \mathrm{~h}$ the exponential growth phase was observed. Stationary phase seems to have been reached at 120 hours. The maximum $\mathrm{OD}_{600 \mathrm{~nm}}$ value was $0.902 \pm 0.017$ at $168 \mathrm{~h}$.

Figure 2 presents the obtained growth curves for L. monocytogenes CECT 4031 in $\mathrm{BHI}$ considering total Viable Cell Counts (VCC) for the assessed sampling time points, at $37^{\circ} \mathrm{C}(\mathrm{A})$ and at $12^{\circ} \mathrm{C}(\mathrm{B})$.

At $37^{\circ} \mathrm{C}$, a stationary phase can be observed in the first 18 $\mathrm{h}$ of incubation, however the maximum value of VCC $9.484 \pm$ $0.678 \log \mathrm{cfu} / \mathrm{ml}$ was obtained at $26 \mathrm{~h}$. At $12^{\circ} \mathrm{C}$, there seems to be a potential lag phase of approximately 48 hours, and from $48 \mathrm{~h}$ to $120 \mathrm{~h}$ the exponential growth phase can be observed. Stationary phase seems to have been reached at 120 hours after inoculation. The maximum value of VCC reached was 9,277 $\pm 0,210 \log \mathrm{cfu} / \mathrm{ml}$ at $168 \mathrm{~h}$. Castro [26] obtained similar results when studying the growth of L. monocytogenes in packaged raw milk, in which, from initial low counts, L. monocytogenes was able to develop to $4.3 \pm 0.4 \mathrm{log} \mathrm{cfu} / \mathrm{ml}$ at refrigerated temperatures $\left(10^{\circ} \mathrm{C}\right)$.

Temperature had a considerable influence on L. monocytogenes growth, because although initial and final concentrations are similar for both temperatures, the time needed to reach final concentration was higher for the lower temperature $\left(12{ }^{\circ} \mathrm{C}\right)$. In order to reach approximate maximum concentrations, around $18 / 20$ hours were needed at $37^{\circ} \mathrm{C}$ and $5 / 6$ days at $12^{\circ} \mathrm{C}$. This was observed when applying both $\mathrm{OD}_{600 \mathrm{~nm}}$ and VCC measurements.

The correlation curves obtained for L. monocytogenes 4031 using $\mathrm{OD}_{600 \mathrm{~nm}}$ and $\mathrm{VCC}$ are shown in Figure $3 \mathrm{~A}\left(37^{\circ} \mathrm{C}\right)$ and Figure $3 \mathrm{~B}\left(12^{\circ} \mathrm{C}\right)$.
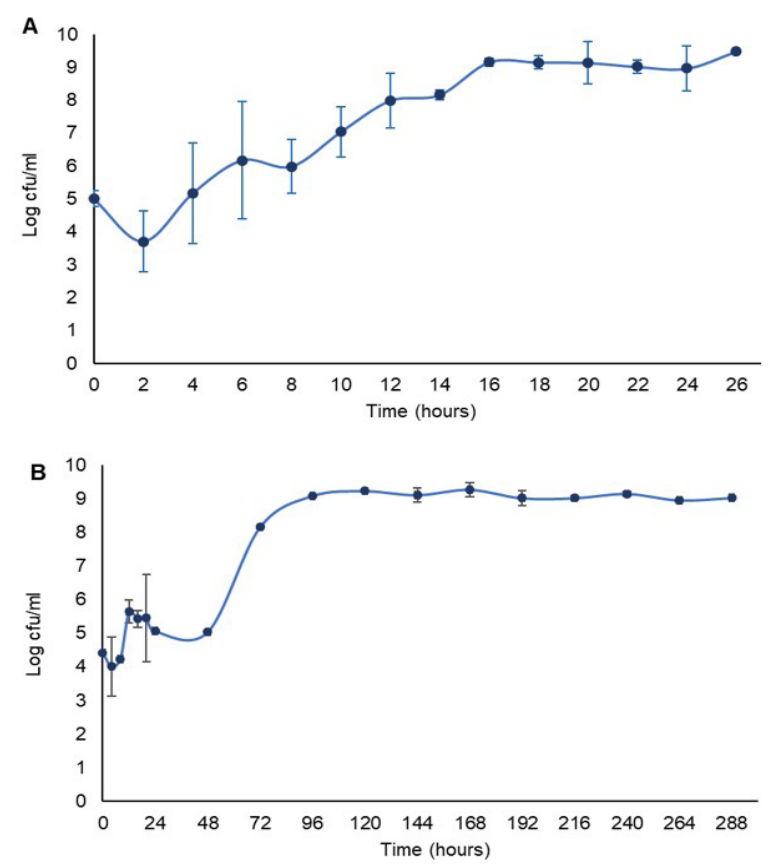

Figure 2: Growth curves of L. monocytogenes CECT 4031 at (A) $37^{\circ} \mathrm{C}$ for $26 \mathrm{~h}$, and (B) at $12^{\circ} \mathrm{C}$ for 12 days, obtained from average and standard deviation (error bars) of viable cell counts.
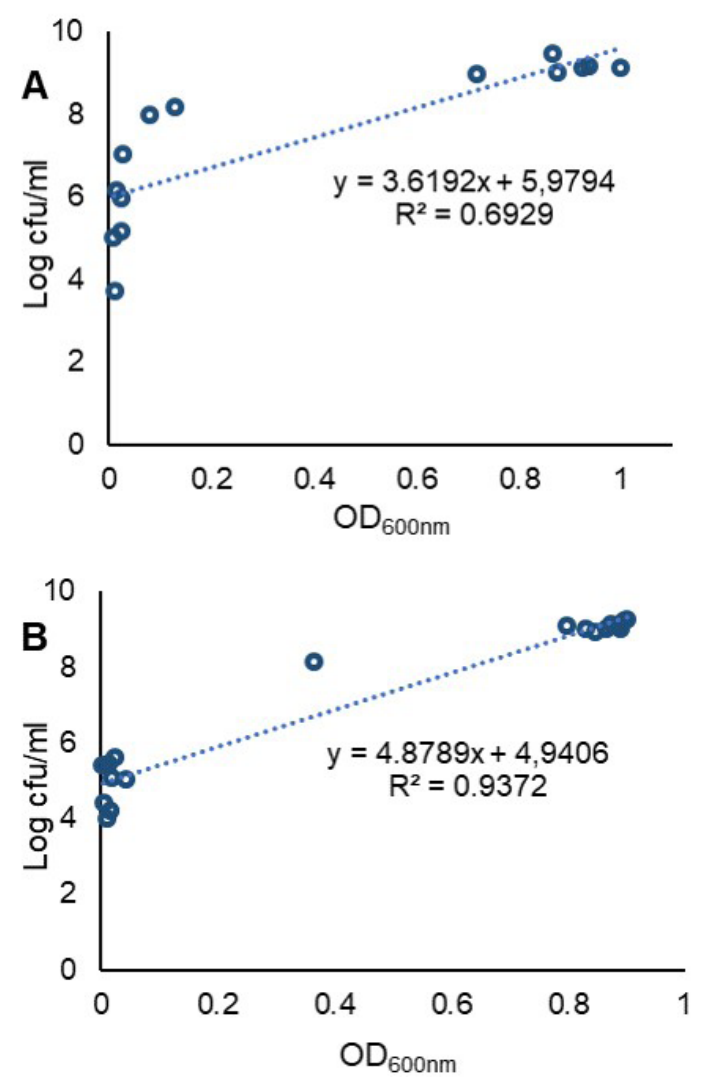

Figure 3: Scattered plot of experimental $\mathrm{OD}_{600 \mathrm{~nm}}$ and VCC for $L$. monocytogenes CECT 4031 at (A) $37^{\circ} \mathrm{C}$ and (B) $12^{\circ} \mathrm{C}$. 
When comparing experimental $\mathrm{OD}_{600 \mathrm{~nm}}$ and VCC results (Table 2), although a good correlation was observed between both methods, Pearson correlation and $\mathrm{R}^{2}$ were higher at $12^{\circ} \mathrm{C}$.

Table 2: Correlation analysis between $\mathrm{OD}_{600 \mathrm{~nm}}$ measurements and VCC.

\begin{tabular}{|c|c|c|c|}
\hline Temperature & Pearson correlation & $\begin{array}{c}95 \% \text { confidence } \\
\text { interval (IC) }\end{array}$ & $\mathbf{R}^{2}$ \\
\hline $37 \circ \mathrm{C}$ & 0.8324 & 0.5404 to 0.9454 & 0.6929 \\
\hline $12 \circ \mathrm{C}$ & 0.9681 & 0.9145 to 0.9883 & 0.9372 \\
\hline
\end{tabular}

At $37^{\circ} \mathrm{C}$, the $R^{2}$ value $(0.6929)$ revealed a low adjustment/ fit when using $\mathrm{OD}_{600 \mathrm{~nm}}$ to estimate VCC. This difference may be related to the fact that optical density measures the turbidity of a suspension, and because of that its relationship with cell concentration may not be linear (deposits of non-viable cells in suspension are also measured as total number of cells). Some authors defend that the difference between both methods is especially evident when assessing growth parameters of isolates in stressful conditions, as morphological changes in the cell may result in optical density values that do not reflect the actual cell numbers [27-29]. Jones, Gill, and McMullen [30] showed that cold adaptation can sometimes cause cell elongation, as cells further increase in cell length before dividing to normal cell length, strongly affecting the relationship between the optical density levels reached and the estimated log cfu/ml.

Nonetheless, the correlation of both methods was high, indicating that VCC values can be reliably inferred through optical density measurements with the use of calibration equations, delivering fast and effective results.

\section{Curve fitting and growth parameters estimation}

For each temperature and using VCC values, growth curves were built by fitting experimental data to the Baranyi's DMFit online version.
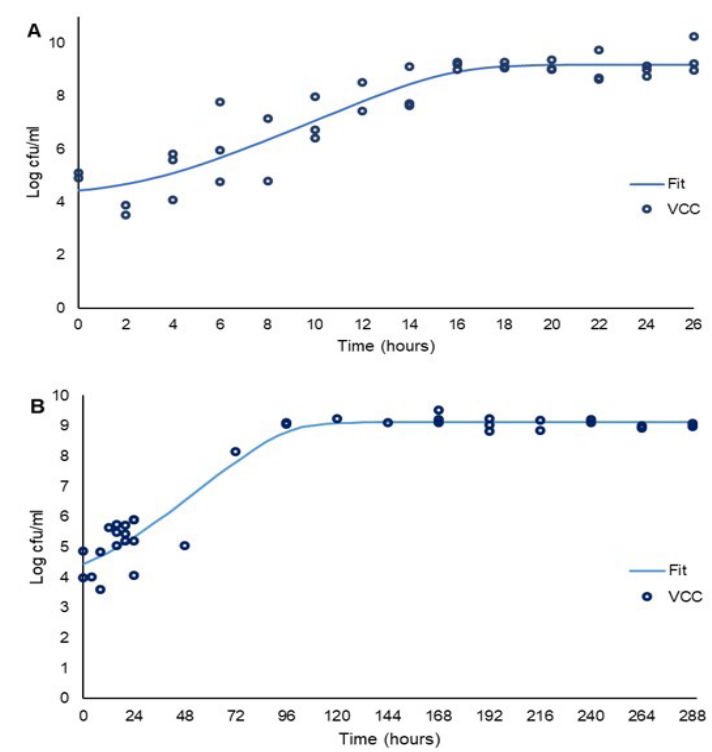

Figure 4: L. monocytogenes CECT $4031 \mathrm{VCC}$ (log cfu/ml) fitted with Baranyi and Roberts model. (A) Incubation for 26 hours at $37^{\circ} \mathrm{C}\left(\mathrm{R}^{2}\right.$ : 0.845; SE: 0.748). (B) Incubation for 12 days at $12^{\circ} \mathrm{C}\left(\mathrm{R}^{2}\right.$ : 0.937; SE: 0.530).

At $37^{\circ} \mathrm{C}$, L. monocytogenes CECT 4031 concentration peaked at $21 \mathrm{~h}$ reaching $9.184 \pm 0.204 \mathrm{log} \mathrm{cfu} / \mathrm{ml}$ (Figure $4 \mathrm{~A}$ ) and remaining stable until the end of incubation time (stationary phase). At $12^{\circ} \mathrm{C}$, L. monocytogenes CECT 4031 reached a maxi- mum final concentration of $9.117 \pm 0.133 \log \mathrm{cfu} / \mathrm{ml}$ after 144 $\mathrm{h}$ (Figure 4B) and remained stable until the end of incubation time (stationary phase).

The obtained $\mathrm{R}^{2}$ results for both temperatures revealed a good fit of the model to experimental data.

Table 3: Maximum growth rate $\left(\mu_{\max }\right)$, lag time $(\lambda)$, initial $\left(C_{0}\right)$ and final $\left(C_{f}\right)$ concentrations (mean $\pm \mathrm{SD}$ ) for L. monocytogenes CECT 4031 estimated by DMFit Model using VCC results, at $37^{\circ} \mathrm{C}$ and $12^{\circ} \mathrm{C}$.

\begin{tabular}{|l|c|c|c|c|}
\hline $\begin{array}{c}\text { Temper- } \\
\text { ature }\end{array}$ & $\begin{array}{c}\boldsymbol{\mu}_{\max } \\
(\log \mathrm{cfu} / \mathrm{ml} / \mathrm{h})\end{array}$ & $\lambda(\mathrm{h})$ & $\begin{array}{c}\mathrm{C}_{0} \\
\text { (log cfu/ml) }\end{array}$ & $\begin{array}{c}\mathbf{C}_{\mathrm{f}} \\
\text { (log cfu/ml) }\end{array}$ \\
\hline $\mathbf{3 7 ^ { \circ } \mathbf { C }}$ & $0.375 \pm 0.072$ & $\begin{array}{c}3.026 \pm \\
2.263\end{array}$ & $4.446 \pm 0.436$ & $9.184 \pm 0.204$ \\
\hline $\mathbf{1 2} \mathbf{C}^{\circ} \mathbf{C}$ & $0.054 \pm 0.001$ & $\begin{array}{c}9.856 \pm \\
11.681\end{array}$ & $4.454 \pm 0.289$ & $9.117 \pm 0.133$ \\
\hline
\end{tabular}

Considering the obtained estimated growth parameters (Table 3), $\mu_{\text {max }}$ at $37^{\circ} \mathrm{C}$ was higher than at $12^{\circ} \mathrm{C}$, and a longer lag phase was observed at this temperature $\left(12^{\circ} \mathrm{C}\right)$. The longer lag phase at $12^{\circ} \mathrm{C}$ could be due to an adaptation period to lower temperatures. Similar growth parameters were obtained by Pla [31], when assessing L. monocytogenes CECT 4031 growth in Tryptic soy broth supplemented with $0.6 \%$ yeast extract at $37{ }^{\circ} \mathrm{C}$ $\left(\mu_{\max }=0.447\right.$ and $\lambda=1.86$ ), and by Wang [32] when studying the growth of L. monocytogenes in $\mathrm{BHI}$ at $10^{\circ} \mathrm{C}\left(\mu_{\max }=0.066\right.$ and $\lambda$ $=17 \mathrm{~h}$ ).

More time was needed for L. monocytogenes to grow at $12^{\circ} \mathrm{C}$ and reach the same concentrations as those obtained at $37^{\circ} \mathrm{C}$. However, final concentrations of the pathogen were very similar, emphasizing the ability of L. monocytogenes to grow at refrigerated temperatures, as the ones used in food producing rooms at industrial facilities. In fact, after $5 / 6$ days of incubation at $12^{\circ} \mathrm{C}$, the levels of $\mathrm{L}$. monocytogenes were similar to the ones reached at $37^{\circ} \mathrm{C}$.

Predictions obtained from Baranyi's model using L. monocytogenes VCC at both temperatures were compared to the estimated growth using ComBase Predictor Growth model (Figure 5).
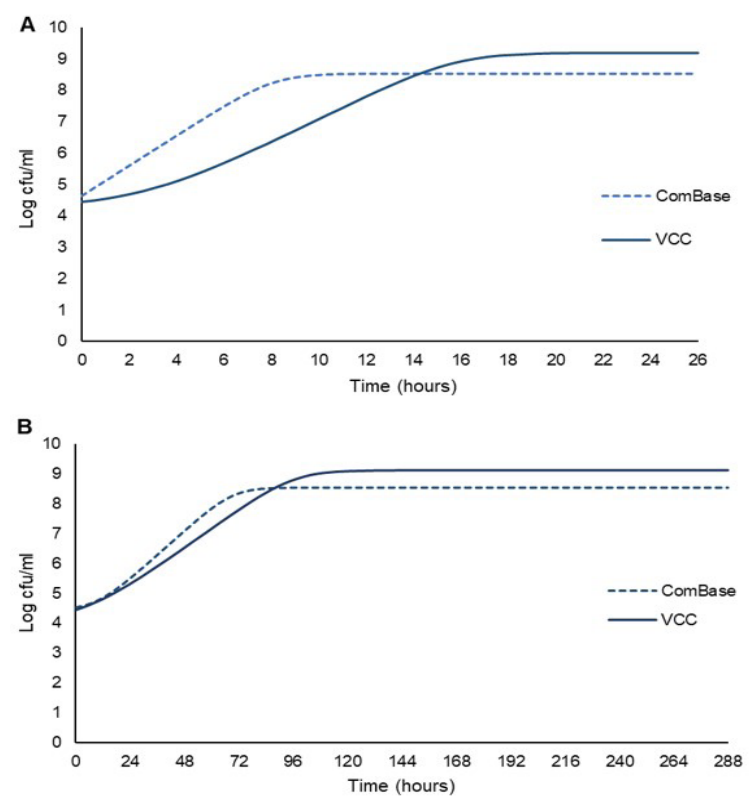

Figure 5: Comparison of L. monocytogenes fitted growth curves obtained from VCC and the online software Combase Predictor Growth Model at (A) at $37^{\circ} \mathrm{C}$ for $26 \mathrm{~h}$ and (B) at $12^{\circ} \mathrm{C}$ for 12 days. 
In general, predictions from ComBase Predictor growth model and this study's results were quite similar. However, when considering the temperature of $37^{\circ} \mathrm{C}$, the growth curve based on VCC presented lower values until $14 \mathrm{~h}$ of incubation, but higher maximum values when compared with ComBase estimated growth curve. The stationary phase was reached sooner in ComBase estimated growth curve. Also, $\mu_{\max }$ obtained with ComBase predictor was of $0.480 \log \mathrm{cfu} / \mathrm{ml} / \mathrm{h}$, higher when compared to the experimental data $\mu_{\max }(0.375 \pm 0.072 \log \mathrm{cfu} /$ $\mathrm{ml} / \mathrm{h}$, Table 3).

At $12^{\circ} \mathrm{C}$, the stationary phase was reached later in the estimated growth curve based on VCC. ComBase growth curve presents lower maximum log $\mathrm{cfu} / \mathrm{ml}$ values. Considering the maximum growth rate $\left(\mu_{\max }\right)$ obtained with ComBase predictor, at $12^{\circ} \mathrm{C}$ a $\mu_{\max }$ of $0.068 \mathrm{log} \mathrm{cfu} / \mathrm{ml} / \mathrm{h}$ was estimated, which was higher than the experimental data $\mu_{\max }(0.054 \pm 0.001$ log cfu/ $\mathrm{ml} / \mathrm{h}$, Table 3).

\section{Calibration curves}

A calibration equation for each strain in the study was obtained by performing three independent calibration curves, in which viable cell counts were plotted against $\mathrm{OD}_{600 \mathrm{~nm}}$ data (Figure 6), allowing a given concentration $(\mathrm{cfu} / \mathrm{ml})$ to be determined from the $O D_{600 n m}$ value assessed using a spectrophotometer.

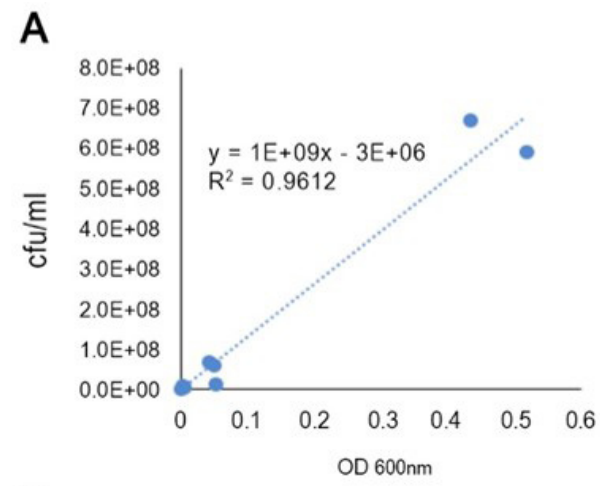

B

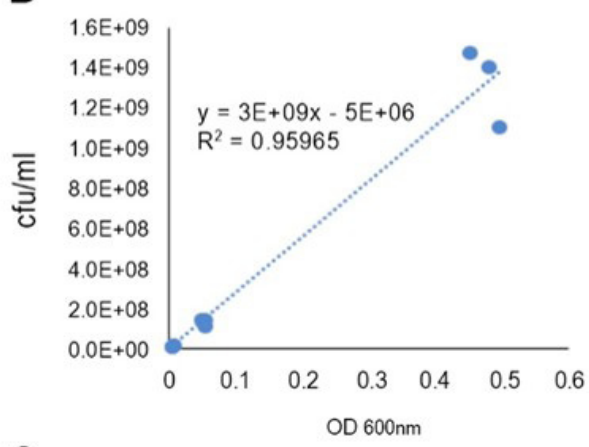

C

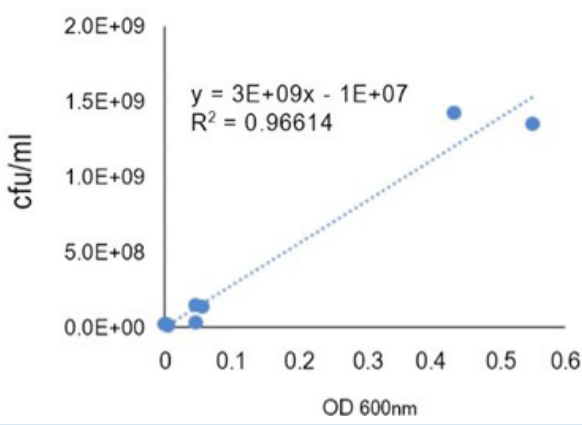

Figure 6: Plot of the observed $\mathrm{OD}_{600 \mathrm{~nm}}$ against the VCC (cfu/ml) for (A) Listeria monocytogenes CECT 4031, (B) Listeria monocytogenes CECT 935 and (C) Listeria monocytogenes CECT 937. Each value corresponds to the mean of three replicates.
Regression parameters and goodness of fit $\left(R^{2}\right)$ of the calibration curve are shown in Table 4.

Table 4: Main statistical parameters for the regression curve obtained for L. monocytogenes strains' calibration curves.

\begin{tabular}{|c|c|c|c|}
\hline L. monocytogenes strain & Slope & Intercept & $\mathbf{R}^{2}$ adjusted \\
\hline CECT 4031 & $1 \times 10^{9}$ & $3 \times 10^{6}$ & 0.9987 \\
\hline CECT 935 & $3 \times 10^{9}$ & $5 \times 10^{6}$ & 0.9597 \\
\hline CECT 937 & $3 \times 10^{9}$ & $1 \times 10^{7}$ & 0.9661 \\
\hline
\end{tabular}

Results indicate a high correlation between $\mathrm{OD}_{600 \mathrm{~nm}}$ values and $\mathrm{cfu} / \mathrm{ml}$ (coefficient of determination, $\mathrm{R}^{2}=0.9987$ ), which indicates that the method is reliable for quantifying L. monocytogenes strains. Pearson's correlation coefficient indicates a strong positive correlation between $\mathrm{cfu} / \mathrm{ml}$ and $\mathrm{OD}_{600 \mathrm{~nm}}(\rho=$ $0.9994, p<0.0001)$. Similar results were obtained by RipollesAvila [33] for L. monocytogenes CECT 935.

\section{Biofilm formation assay}

The assessed strains in biofilms revealed cvOD values ranging from $0.068 \pm 0.001$ to $0.1078 \pm 0.005$ and viable cell counts of $6.013 \pm 0.346 \mathrm{log} \mathrm{cfu} / \mathrm{ml}$ to $7.391 \pm 0.227 \mathrm{log} \mathrm{cfu} / \mathrm{ml}$ after 5 days of growth in polystyrene microtiter wells (Figure 7).

According to Stepanović, Cirković, Ranin, and Svabić-Vlahović [22] classification, all the strains revealed a weak biofilm- forming ability. Meloni [25] obtained similar results when studying L. monocytogenes isolates from fermented sausage processing plants: $65 \%$ of all isolates were weak biofilm producers.

While L. monocytogenes CECT 4031 revealed the lowest values for both VCC and CVOD at $30^{\circ} \mathrm{C}$, L. monocytogenes CECT 935 exhibited the highest biofilm-forming ability, based on both biofilm formation parameters. Similar results were obtained by Ripolles-Avila [33] when studying the quantification of cell density within L. monocytogenes biofilms based on CVOD.

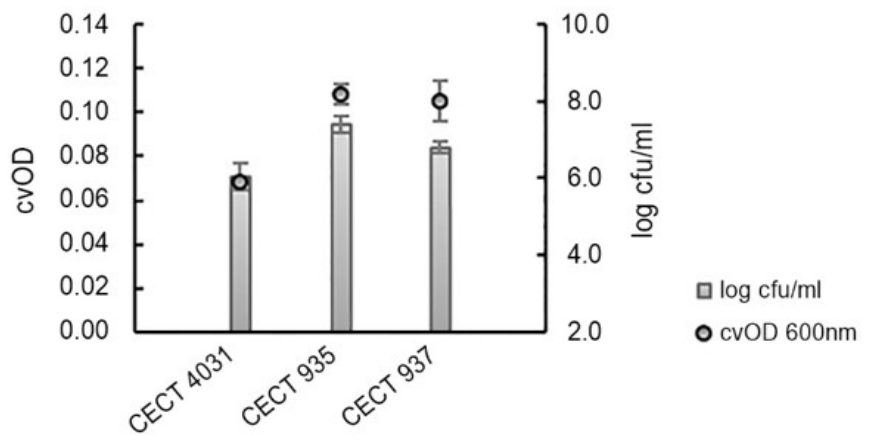

L. monocytogenes strains

Figure 7: Average and standard deviation of $\log \mathrm{cfu} / \mathrm{ml}$ and cVOD of the assessed 5-day L. monocytogenes biofilms at $30^{\circ} \mathrm{C}$.

Considering the selected methods to analyse biofilm formation - VCC (log cfu/ml) and CVOD, a positive and strong correlation $(\rho=0.7749, p=0.009)$ was obtained. This coefficient value indicates that both methods presented a good relation, being reliable to quantifying $\mathrm{L}$. monocytogenes biofilm formation and complementing each other.

Differences between CVOD and VCC results are due to the nature of each method determination: While cVOD measures the turbidity of a suspension and quantifies total biomass (via- 
ble and non-viable cells, and extracellular matrix components), VCC only considers live cells [34]. Although monitoring biofilm formation with VCC is time-consuming, laborious and expensive because the technique is based on serial dilutions and plating methods, it remains the method of reference for monitoring bacterial growth $[27,29,35]$. On the other hand, cvOD method may overestimate the number of viable, attached cells $[34,36]$. Additionally, stressful conditions may induce morphological changes in cells, such as cell elongation, strongly affecting the relationship between cVOD and VCC [29].

For further testing, L. monocytogenes CECT 935 and CECT 4031 were selected based on Tukey's test results for VCC and cVOD, that presented statistically significant differences $(p<$ 0.05 ) in both biofilm formation parameters.

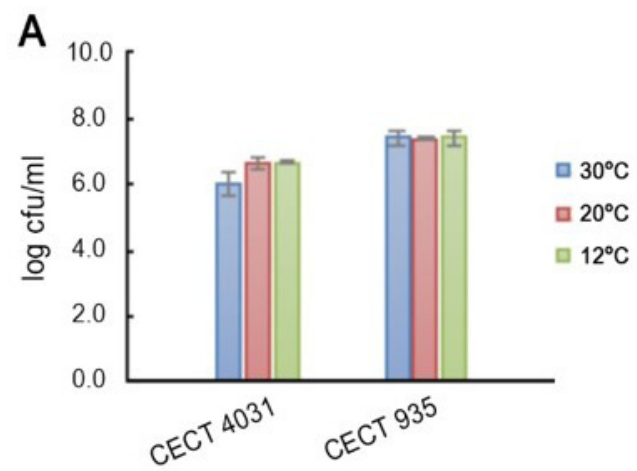

L. monocytogenes strains

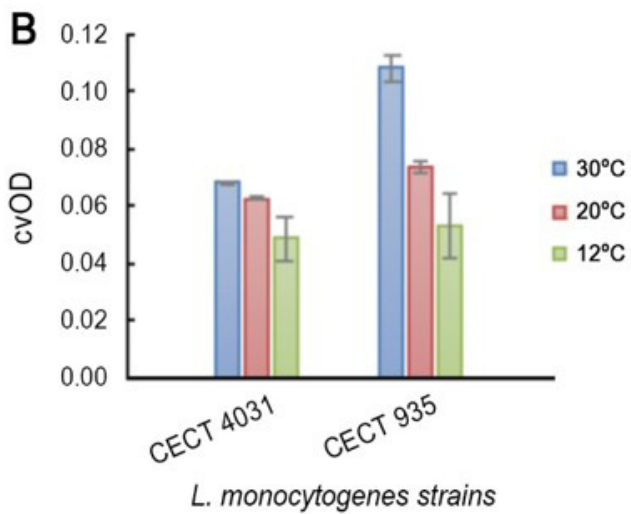

Figure 8: Average and SD (error bars) of the selected L. monocytogenes strains in 5-day old biofilms considering (A) Viable cells counts (log cfu/ml) and (B) Crystal Violet staining (cvOD).

All of the tested L. monocytogenes isolates were able to form biofilm at $30^{\circ} \mathrm{C}, 20^{\circ} \mathrm{C}$ and $12^{\circ} \mathrm{C}$ (Figure 8). Although there were no significant differences $(p=0.958)$ in biofilm formation at different temperatures considering VCC values (Figure $8 \mathrm{~A}$ ), using cvOD (Figure $8 B$ ) significant differences $(p=0.0002)$ were observed in biofilm formation for the considered temperatures.

It is important to underline that the studied L. monocytogenes strains revealed biofilm-forming ability at refrigerated processing environment temperatures $\left(12^{\circ} \mathrm{C}\right.$ and $\left.20^{\circ} \mathrm{C}\right)$, as the ones used in refrigerated producing rooms in the food industry. Still, the highest biofilm formation occurred at $30^{\circ} \mathrm{C}$ for all $\mathrm{L}$. monocytogenes tested strains, confirming that temperature influences L. monocytogenes biofilm formation, as has been previously reported. Tomicić [37] reported that growth conditions affected biofilm formation, revealing the lowest biofilm formation for the lowest tested temperature. Similar results were obtained by Russo [2] when testing L. monocytogenes biofilmforming ability on polystyrene under different temperatures. In fact, Abeysundara [38] observed that biofilm formation was influenced by temperature, resulting in decreased biofilm formation with decreasing temperature. Di Bonaventura [39] demonstrated that biofilm production on polystyrene surfaces at $37{ }^{\circ} \mathrm{C}$ was significantly higher than at $4^{\circ} \mathrm{C}$. However, according to Puga [40], some evidence suggests that persistence of certain strains may be enhanced by low temperatures adaptation mechanisms. Temperature may influence flagella formation actively involved in the adhesion to different surfaces [2].

\section{Conclusions}

In this study, when fitting planktonic L. monocytogenes isothermal growth experimental data to Baranyi's model, a good fit was obtained for both temperatures. The estimated growth parameters confirmed that $\mu \mathrm{max}$ at $37^{\circ} \mathrm{C}$ was higher than at $12^{\circ} \mathrm{C}$, and a longer lag phase was observed at this temperature, indicating an adaptation period to lower temperatures. Still, L. monocytogenes final concentrations were identical, emphasizing its ability to grow at refrigerated temperatures. Additionally, experimental results from the isothermal growth assay and ComBase Predictor growth model were rather similar, but higher $\mu$ max were estimated for both temperatures by the predictor model.

Calibration curves using $\mathrm{OD}_{600 \mathrm{~nm}}$ and VCC results indicated a strong positive correlation of both parameters, confirming the reliability of both parameters to estimate L. monocytogenes concentration.

The studied L. monocytogenes strains demonstrated biofilmforming ability at $12^{\circ} \mathrm{C}, 20^{\circ} \mathrm{C}$ and $30^{\circ} \mathrm{C}$ after 5 days of growth and all revealed to be weak biofilm producers. Although there were no significant differences in biofilm formation at different temperatures considering VCC values, using cVOD significant differences were found and the highest biofilm formation occurred at $30^{\circ} \mathrm{C}$.

Still, a positive and strong correlation was found between VCC and cVOD results, which complement each other in biofilm formation assessment.

Overall, this study's outcomes contribute with important preliminary data on L. monocytogenes growth at different temperatures, whether in the planktonic form or in biofilms. The gathered data will further assist predictive modeling and risk assessment studies, improving possible interventions and mitigation strategies to control this important foodborne pathogen.

\section{Funding}

This work was financed by national funds through FCT Foundation for Science and Technology, I.P., within the scope of project UIDB/00276/2020.

\section{Acknowledgments}

The authors gratefully acknowledge Maria Helena Fernandes, Maria José Fernandes and Maria Paula Silva for the technical support and Carla Carneiro for the discussion time. We acknowledge the logistic support of CIISA - Centro de Investigação Interdisciplinar em Sanidade Animal, Faculdade de Medicina

Veterinária, Universidade de Lisboa, Avenida da Universidade Técnica, 1300-477 Lisboa, Portugal. 


\section{References}

1. European Food Safety Authority (EFSA) and European Centre for Disease Prevention and Control (ECDC). The European Union One Health 2018 Zoonoses Report. EFSA J. 2019; 17: 5926.

2. Russo P, Hadjilouka A, Beneduce L, Capozzi V, Paramithiotis S, et al. Effect of different conditions on Listeria monocytogenes biofilm formation and removal. Czech J Food Sci. 2018; 36: 208214.

3. Sahu SN, Kim B, Ferguson M S, Zink D L, Datta A R. Growth potential of Listeria monocytogenes in artificially contaminated celery and chicken salad. Food Control. 2016; 73: 1229-1236.

4. Listeriosis DS: A Rare but Deadly Disease. Clin Microb Newsl. 2015; 37 (17): 135-140.

5. Buchanan RL, Gorris LGM, Hayman MM, Jackson TC, Whiting RC. A review of Listeria monocytogenes: An update on outbreaks, virulence, dose-response, ecology, and risk assessments. Food Control. 2017; 75: 1-13.

6. Li C, Huang L, Hwang CA, Chen J. Growth of Listeria monocytogenes in salmon roe - A kinetic analysis. Food Control. 2016; 59: 538-545.

7. Henriques AR, Fraqueza MJ. Listeria monocytogenes: Incidence, Growth Behavior and Control. New York, NY, USA: Nova Science Publishers Inc. 2015; 71-103.

8. Olszewska MA, Zhao T, Doyle MP. Inactivation and induction of sublethal injury of Listeria monocytogenes in biofilm treated with various sanitizers. Food Control. 2016; 70: 371-379.

9. Bonsaglia ECR, Silva NCC, Fernandes JA, Araújo Junior JP, Tsunemi $\mathrm{MH}$, et al. Production of biofilm by Listeria monocytogenes in different materials and temperatures. Food Control. 2014; 35 : 386-391.

10. Kannan S, Balakrishnan J, Govindasamy A. Listeria monocytogenes - Amended understanding of its pathogenesis with a complete picture of its membrane vesicles, quorum sensing, biofilm and invasion. Microb Pathog. 2020; 149: 104575.

11. Allen KJ, Wałecka-Zacharska E, Chen JC, Katarzyna K-P, Devlieghere $\mathrm{F}$, et al. Listeria monocytogenes - An examination of food chain factors potentially contributing to antimicrobial resistance. Food Microbiol. 2016; 54: 178-189.

12. Ortiz S, López V, Martínez-Suárez JV. Control of Listeria monocytogenes contamination in an Iberian pork processing plant and selection of benzalkonium chloride-resistant strains. Food Microbiol. 2014; 39: 81-88.

13. Szczawiński J, Szczawińska ME, Łobacz A, Tracz M, JackowskaTracz A. Modelling the growth rate of Listeria monocytogenes in cooked ham stored at different temperatures. J Vet Res. 2017; 61: 45-51.

14. Chen R, Skeens J, Orsi RH, Wiedmann M, Guariglia-Oropeza V. Pre-growth conditions and strain diversity affect nisin treatment efficacy against Listeria monocytogenes on cold-smoked salmon, Int J Food Microbiol. 2020; 333: 108793.

15. Bernardo R, Barreto AS, Nunes T, Henriques AR. Estimating Listeria monocytogenes Growth in Ready-to-Eat Chicken Salad Using a Challenge Test for Quantitative Microbial Risk Assessment. Risk Anal. 2020.

16. Tirloni E, Stella S, de Knegt LV, Gandolfi G, Bernardi C, et al. A quantitative microbial risk assessment model for Listeria monocytogenes in RTE sandwiches. Microb Risk Anal. 2018; 9: 11-21.
17. Álvarez-Ordóñez A, Leong D, Hickey B, Beaufort A, Jordan K. The challenge of challenge testing to monitor Listeria monocytogenes growth on ready-to-eat foods in Europe by following the European Commission (2014) Technical Guidance document. Food Res Int. 2015; 75: 233-243.

18. Takahashi H, Takahashi T, Miya S, Yokoyama H, Kuda T, et al. Growth inhibition effects of ferulic acid and glycine/sodium acetate on Listeria monocytogenes in coleslaw and egg salad. Food Control. 2015; 57: 105-109.

19. Baranyi J, Roberts TA. A dynamic approach to predicting bacterial growth in food. Int J Food Microbiol. 1994; 23: 277-294.

20. Baranyi J, Roberts TA, McClure P. A non-autonomous differential equation to model bacterial growth. Food Microbiol. 1993; 10: 43-59.

21. Romanova NA, Gawande PV, Brovko LY, Griffiths, MW. Rapid methods to assess sanitizing efficacy of benzalkonium chloride to Listeria monocytogenes biofilms. J. Microbiol. Methods. 2007; 71: 231-237.

22. Stepanović S, Cirković I, Ranin L, Svabić-Vlahović M. Biofilm formation by Salmonella spp. and Listeria monocytogenes on plastic surface. Lett. Appl. Microbiol. 2004; 38: 428-432.

23. Davenport KW, Daligault HE, Minogue TD, Bishop-Lilly TA, Bruce DC, P. et al. Whole-Genome Sequence of Listeria monocytogenes Type Strain 53 XXIII. Genome Announc. 2014; 2: e0097014.

24. Beaufort A, Bergis H, Lardeux AL. Technical guidance document for conductiong shelf-life studies on Listeria monocytogenes in ready-to-eat foods. European Union Reference Laboratory for Listeria monocytogenes. 2014; 3: 1-47.

25. Meloni D, Consolati SG, Mazza R, Mureddu A, Fois F, et al. Presence and molecular characterization of the major serovars of Listeria monocytogenes in ten Sardinian fermented sausage processing plants. Meat Sci. 2014; 97: 443-450.

26. Castro $\mathrm{H}$, Ruusunen $\mathrm{M}$, Lindström M. Occurrence and growth of Listeria monocytogenes in packaged raw milk. Int J Food Microbiol. 2017; 261: 1-10.

27. Baty F, Flandrois JP, Delignette-Muller ML. Modeling the lag time of Listeria monocytogenes from viable count enumeration and optical density data. App Environ Microbiol. 2002; 68: 58165825.

28. Bereksi N, Gavini F, Bénézech T, Faille C. Growth, morphology and surface properties of Listeria monocytogenes Scott $A$ and LO28 under saline and acid environments. J Appl Microbiol. 2002; 92: 556-65.

29. Francois K, Devlieghere F, Standaert A, Geeraerd A, Cools I, et al. Environmental factors influencing the relationship between optical density and cell count for Listeria monocytogenes. J Appl Microbiol. 2005; 99: 1503-1515.

30. Jones T, Gill CO, McMullen LM. Behaviour of log-phase Escherichia coli at temperatures near the minimum for growth. Int J Food Microbiol. 2003; 88: 55-61.

31. Pla ML, Oltra S, Esteban MD, Andreu S, Palop A. Comparison of Primary Models to Predict Microbial Growth by the Plate Count and Absorbance Methods. BioMed Res Int. 2015; 365025.

32. Wang X, Lahou E, De Boeck E, Devlieghere F, Geeraerd A, et al. Growth and inactivation of Salmonella enterica and Listeria monocytogenes in broth and validation in ground pork meat during simulated home storage abusive temperature and home pan-frying. Front Microbiol. 2015; 6: 1161. 
33. Ripolles-Avila C, Ríos Castillo AG, Guerrero-Navarro AE, Rodríguez-Jerez JJ. Reinterpretation of a classic method for the quantification of cell density within biofilms of Listeria monocytogenes. J Microbiol Exp. 2018; 6: 70-75.

34. Ibusquiza PS, Herrera JJR, Cabo ML. Resistance to benzalkonium chloride, peracetic acid and nisin during formation of mature biofilms by Listeria monocytogenes. Food Microbiol. 2011; 28: 418-425.

35. Kwasny SM, Opperman TJ. Static biofilm cultures of Gram-positive pathogens grown in a microtiter format used for anti-biofilm drug discovery. Curr Protoc Pharmacol. 2010; 13: 13 A8.

36. Kadam SR, den Besten HM, van der Veen S, Zwietering $\mathrm{MH}$, Moezelaar $\mathrm{R}$, et al. Diversity assessment of Listeria monocytogenes biofilm formation: Impact of growth condition, serotype and strain origin. Int J Food Microbiol. 2013; 165: 259-264.

37. Tomiĉić R, Cabarkapa I, Vukmirovic D, Tomičić Z. Influence of growth conditions on biofilm formation of Listeria monocytogenes. Food Feed Res. 2016; 43: 19-24.
38. Abeysundara PA, Dhowlaghar N, Nannapaneni R, Schilling MW, Chang S, et al. Growth and biofilm formation by Listeria monocytogenes in cantaloupe flesh and peel extracts on four foodcontact surfaces at $22^{\circ} \mathrm{C}$ and $10^{\circ} \mathrm{C}$. Food Control, 2017; 80: 131142.

39. Di Bonaventura G, Piccolomini R, Paludi D, D'Orio V, Vergara A, et al. Influence of temperature on biofilm formation by Listeria monocytogenes on various food-contact surfaces: Relationship with motility and cell surface hydrophobicity. J Appl Microbiol. 2008; 104: 1552-1561.

40. Puga $\mathrm{CH}$, SanJose C, Orgaz B. Biofilm development at low temperatures enhances Listeria monocytogenes resistance to chitosan. Food Control. 2016; 65: 143-151. 